\title{
The Impact of Transformation of Social Assistance on Financial Inclusion and Welfare of Beneficiary Families
}

\author{
By \\ Arief Fajar Firmansyah ${ }^{1)}$, Suharno ${ }^{2 *}$, Arintoko $^{3)}$ \\ Faculty of Economics and Business, Universitas Jenderal Sudirman \\ ${ }^{*}$ Corresponding Author: suharno@unsoed.ac.id
}

Submission: April 18, 2021; Accepted: April 30, 2021

\begin{abstract}
This study is based on the transformation of the distribution of cash social assistance into non-cash in the City of Tegal. The non-cash distribution is by using a banking account that has a combo card facility, which is a multi-function card that can be used as an ATM card as well as disbursement of social assistance. There is a slice of the objectives of the non-cash transaction referred to as an alternative to accelerate the increase in financial inclusion of the Indonesian population as stated in the National Strategy for Financial Inclusion with the financial inclusion index indicator. This study aims to determine the impact of the transformation of the distribution of social assistance on financial inclusion in Tegal City and the welfare of beneficiary families (KPM). Primary data were collected from questionnaires that have been filled in by KPM and secondary data were obtained from the Central Bureau of Statistics and the Representative Office of Bank Indonesia Tegal. The analytical tool used is a quantitative approach to KPM's response to the distribution of noncash social assistance. As supporting data, in the problem of financial inclusion, analysis tools are used by qualitatively comparing financial inclusion that is generated as a result of the implementation of the distribution of non-cash social assistance to existing financial inclusion. The analysis shows that the acceptance and perception of KPM supports the transformation of non-cash social assistance distribution, this is supported by KPM's interest in using combo cards as a means of saving. On the other hand, the transformation of the distribution of social assistance to non-cash contributes to financial inclusion in the city of Tegal, namely the Agent Laku Pandai (LKD) contributing $75.20 \%$ to banking financial services in Tegal City. From the 4 Welfare Indicator Classifications, it is found that the welfare of KPM has experienced changes in welfare after receiving non-cash social assistance and has improved the welfare of the beneficiary community (KPM).
\end{abstract}

Keywords : Non-Cash Social Assistance, PKH, BPNT

\section{ABSTRAK}

Penelitian ini berlatar belakang transformasi penyaluran bantuan sosial tunai menjadi tunai non di Kota Tegal. Penyaluran non tunai tersebut adalah dengan menggunakan rekening perbankan yang memiliki fasilitas kartu kombo, yaitu kartu multi fungsi yang dapat dijadikan sebagai kartu ATM sekaligus pencairan bantuan sosial. Terdapat irisan tujuan dari transaksi non tunai dimaksud sebagai alternative percepatan peningkatan inklusi keuangan penduduk Indonesia yang tertera dalam Strategi Nasional Keuangan Inklusi dengan indikator indeks keuangan inklusif. Data primer bersumber dari kuisoner yang telah diisi oleh KPM dan data sekunder didapatkan dari Badan Pusat Statistik. Alat analisi yang digunakan adalah dengan pendekatan kuantitatif respon KPM terhadap penyaluran bantuan sosial non tunai. Sebagai data pendukung, dalam permasalahan inklusi keuangan di gunakan alat analisis dengan kualitatif membandingkan inklusi keuangan yang 
ditimbulkan sebagai dampai dari implementasi penyaluran bantuan sosial non tunai terhadap inklusi keungan existing. Dari hasil analisis menunjukan bahwa akseptasi dan persepsi KPM mendukung transformasi penyaluran bantuan sosial non tunai, hal ini didukung dengan minat KPM untuk menggunakan kartu kombo sebagai sarana menabung. Dilain sisi bahwa transformasi penyaluran bantuan sosial menjadi non tunai berkontribusi terhadap inklusi keluangan di kota tegal yaitu Agen Laku Pandai (LKD) memberikan kontribusi sebesar 75,20 \% terhadap layanan finansial perbankan di Kota Tegal. Dari 4 Klasifikasi Indikator Kesejahteraan, diperoleh bahwa kesejahteraan KPM mengalami perubahan kesejahteraan pasca menerima bansos non tunai dan telah meningktakan kesejahteraan keluarga penerima manfaat (KPM).

\section{Kata Kunci : Bantuan Sosial Non Tunai, PKH, BPNT}

\section{INTRODUCTION}

The government, through Bank Indonesia and Otoritas Jasa Keuangan (OJK), is trying to improve financial inclusion and financial literacy. The Consultative Group to Assist the Poor (CGAP-GPFI) defines financial inclusion as a condition in which all working age people are able to get effective access to credit, savings, payment systems and insurance from all financial service providers. The results of the National Financial Literacy Survey (SNLIK) by Otoritas Jasa Keuangan (OJK) in 2019 on the financial inclusion index are indeed very encouraging, namely $76.19 \%$ or an increase of $8.39 \%$ from the previous survey period. Based on regional strata, for cities the financial inclusion index is $83,60 \%$ while for rural areas it is $68.49 \%$. The increase in the financial inclusion index was indicated by government support through the National Strategy for Financial Inclusion (SNKI).

In the National Strategy for Financial Inclusion (SNKI), financial inclusion is defined as the right of everyone to have full access and services from financial institutions in a timely, comfortable, informative, and affordable manner, with full respect for their dignity. Financial services are available to all segments of society, with special attention to the poor, productive people, migrant workers and residents in remote areas through three main variables: access, usage and quality.

The direction of the President of the Republic of Indonesia regarding the transformation of non-cash distribution of social assistance (bansos) in the Limited Working Meeting on April 26, 2016 emphasized that any distribution of social assistance will be carried out in non-cash form through the banking system and integrated into one card (combo card). This is in line with the National Financial Inclusion Strategy Program (SNKI). So that since October 2016 the Program Keluarga Harapan (PKH) and since February 23, 2017 Bantuan Pangan Non Tunai (BPNT) has been implemented non-cash.

Non-cash social assistance (bansos) has 2 (two) sides, namely as a strategy of poverty alleviation programs and to introduce access to non-cash finance at low cost to poor beneficiary families (KPM). In order to improve the effectiveness and efficiency of social assistance distribution and encourage inclusive finance, the government and authorities related to the payment system initiated the integration of BPNT and PKH aid distribution through the use of combo cards called The Prosperous Family Card (KKS). Combo card is a payment instrument that has electronic money and savings features that are used as a medium of channeling various bansos programs for KPM, so that eventually KPM will have access to banking. Implementation of non-cash social assistance distribution to KPM other than through banking ATM channels is through E Waroeng network integrated with smart selling agents (LKD).

As a National Program, Tegal City is one of 44 cities selected to pilot the implementation of the Non-Cash Food Assistance Program (BPNT) in Indonesia which was implemented in february 2017. Thus the City of Tegal is the first to implement the transformation of the distribution of cash social assistance to non-cash in the former Pekalongan Karesidenan. During 2019, the non-cash distribution of BPNT and PKH by the City of Tegal was carried out to 5,890 beneficiary families (KPM) with a total budget of Rp3,123,550,000.00. 


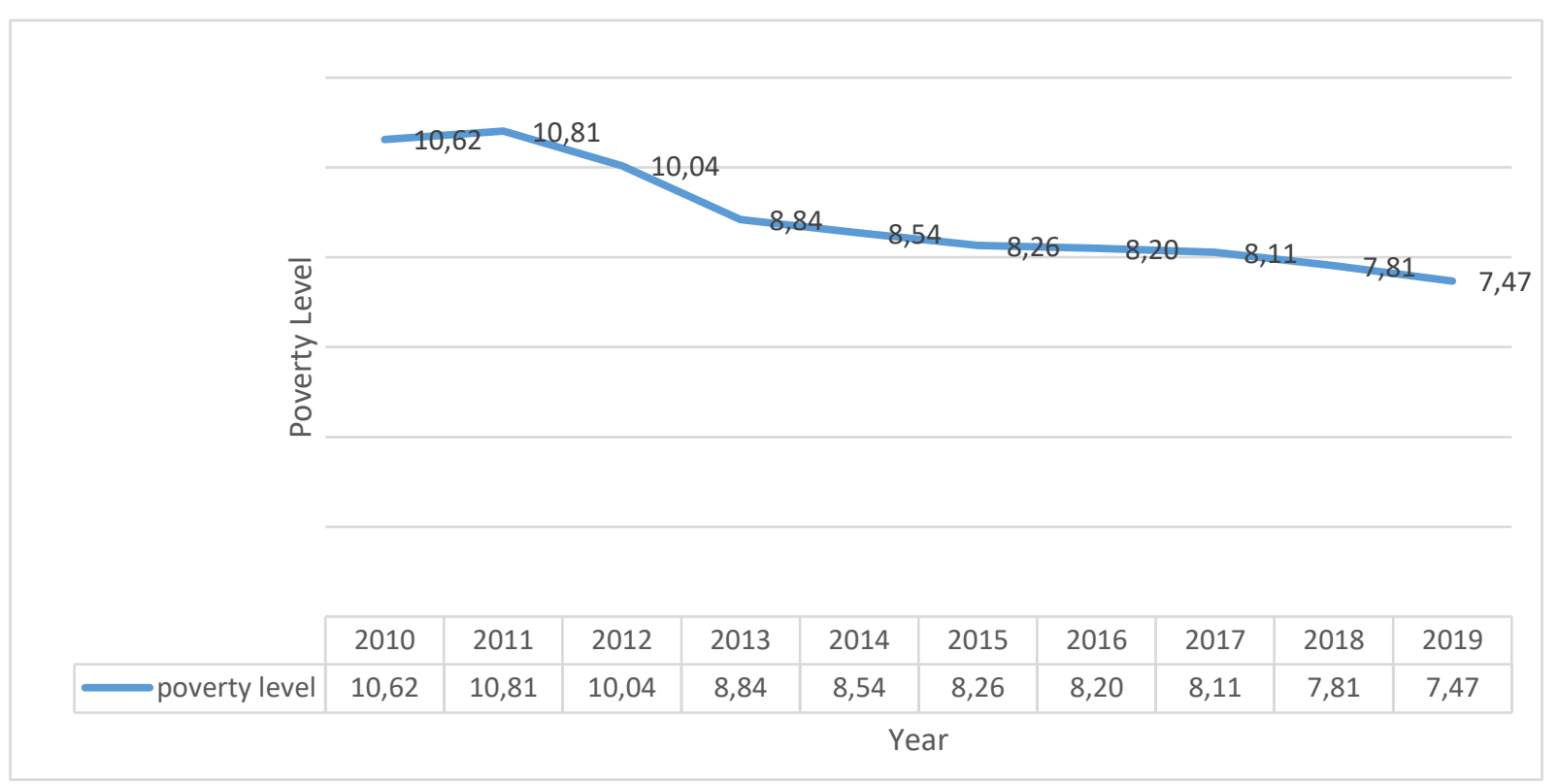

Figure 1. Poverty Rate in Tegal City 2010 - 2019

Source: Central Bureau of Statistics, 2020

From Figure 1. above, it can be concluded that the Tegal City Government has succeeded in overcoming community poverty as reflected in the decline in the poverty rate from year to year, namely $10.62 \%$ in 2010 to $7.47 \%$ in 2019 . However, it is necessary to investigate whether the decline in rates This poverty is also followed by an increase in the welfare level of KPM in accordance with the welfare definition of the BKKBN.

However, the implementation of the BPNT program in various regions is certainly not the same. Several studies on BPNT in other regions have shown mixed results. Research conducted by Risnandar and Wisnu (2018) said that there is still a gap between the performance and the expectations of the beneficiary families (KPM) regarding the availability of foodstuffs and the infrastructure used.

Widianto (2016) in his research stated that the capital expenditure made by the Tegal City Government has a positive effect on economic growth. However, poverty reduction with an indicator of reducing the poverty rate obtained from meeting basic needs is a false poverty rate (Habibullah, 2019).

This study is expected to know the perceptions and acceptances of beneficiary families (KPM) in TEGAL City to the transformation of social assistance distribution to non-cash, the potential for saving beneficiary families (KPM) with non-cash social assistance, the level of Inclusive Financial Index for Tegal City after the transformation of social assistance distribution to non-cash, and the level of classification of the welfare of beneficiary families according to BKKBN after the transformation of social assistance distribution to non-cash.

Act No. 52 of 2009 article 1 point 10 mentioned that prosperous families are part of the characteristics of quality families, namely families formed by legal marriages and characterized as prosperous, healthy, advanced, independent, having ideal number of children, forward-looking, responsible, harmonious, and devoted to God Almighty. According to article 1 point 11 family resilience and well-being are defined as family conditions that have tenacity and toughness and contain material physical abilities to live independently and develop themselves and their families to live harmoniously in improving the welfare of birth and inner happiness. The basis of this law becomes a reference in measuring the level of family welfare.

In order to accelerate financial inclusion, the government has determined that the distribution of social assistance to the community is carried out in a non-cash. This new system for distributing social assistance is regulated by Presidential Regulation Number 63 of 2017 concerning Non-Cash Distribution of Social Assistance. The distribution of non-cash social assistance to the 
community is considered to be more efficient, right on target, right in amount, on time, on quality, and on administration. Social assistance is assistance in the form of cash or non-cash, goods, or services provided by relevant ministries / agencies at the central and regional levels to a person, family, group or community who is poor, unable, and vulnerable to risk.

A study conducted by Habibullah (2019) revealed that non-cash social assistance is the right step to increase public financial inclusion through the provision of access to affordable financial sector services for the poor. As a development of the research in this study will reveal how the level of acceptance of non-cash social assistance programs and how potential families of social assistance beneficiaries use affordable low-cost financial services for the poor. In addition, this study will reveal what access to financial services contributes the most to financial inclusion based on aspects of the availability of financial services.

\section{METHOD}

This study uses survey methods. The research was conducted through a face-to-face interview survey approach with questionnaire guides designed in a structured manner. This study obtained data directly from the research site in Tegal City. The population of Tegal City social assistance beneficiary families (KPM) in 2019 was 5,890 families, and the sample size was determined using the Slovin formula. Respondents in the study were conducted through purposive sampling technique, namely a nonrandom technique with special characteristics. Respondents are beneficiary families (KPM) of non-cash social assistance (PKH and BPNT) in Tegal City. The data analysis techniques to answer the research questions are 1) Importance Performance Analysis (IPA) to determine the perception and acceptance of non-cash social assistance, 2 ) $t$ test to see the potential savings of KPM recipients and 3 ) the level of contribution of non-cash social assistance distribution to the level of financial inclusion. The calculation method is to compare the number of account ownership through participation as KPM (beneficiary family) PKH and BPNT non-cash social assistance with the total population who have accounts, and 4) Mc Nemar test to see the condition of KPM which will be measured through the fulfillment of needs before and after receiving social assistance.

\section{RESULTS AND DISCUSSIONS}

Importance performance analysis (IPA) is used to determine perceptions and acceptances of non-cash social assistance that the level of customer interest (customer expectation) is measured in relation to what companies should do in order to produce high quality products and services.

\section{GAP analysis}

Gap analysis is a measurement method to determine the gap between the performance of a variable and the expectations of consumers (beneficiary families of social assistance) on these variables. A positive gap (+) will be obtained if the perception score is greater than the expected score, whereas if the expectation score is greater than the perception score, a negative (-) gap will be obtained. The higher the expectation score and the lower the perception score, the bigger the gap. Following are the results of the GAP analysis

Table 1. GAP Analysis For Each Indicator

\begin{tabular}{crcr}
\hline INDICATOR & HOPE & PERCEPTION & \multicolumn{1}{c}{ GAP } \\
\hline Y1 & 3.94 & 4.12 & 0.18 \\
Y2 & 4.47 & 3.93 & -0.54 \\
Y3 & 4.71 & 4.41 & -0.3 \\
Y4 & 4.8 & 4.45 & -0.35 \\
\hline
\end{tabular}

Source: Processed Data, 2021

Based on table 1, it is found that the perception of non-cash social assistance KPM on the right-ontarget dimension has a positive value, while the practicality, on-time, and precise dimensions have a negative value. However, the gap value generated by each dimension is relatively small. 


\section{Difference test}

Based on the output of the difference test table, it was found that Sig $0.198>$ alpha 0.05 . Therefore, statistically, it can be concluded that there is no gap between expectations and perceptions of KPM on the transformation of social assistance distribution to non-cash, so that KPM supports and accepts the transformation of social assistance.

\section{IPA Matrix}

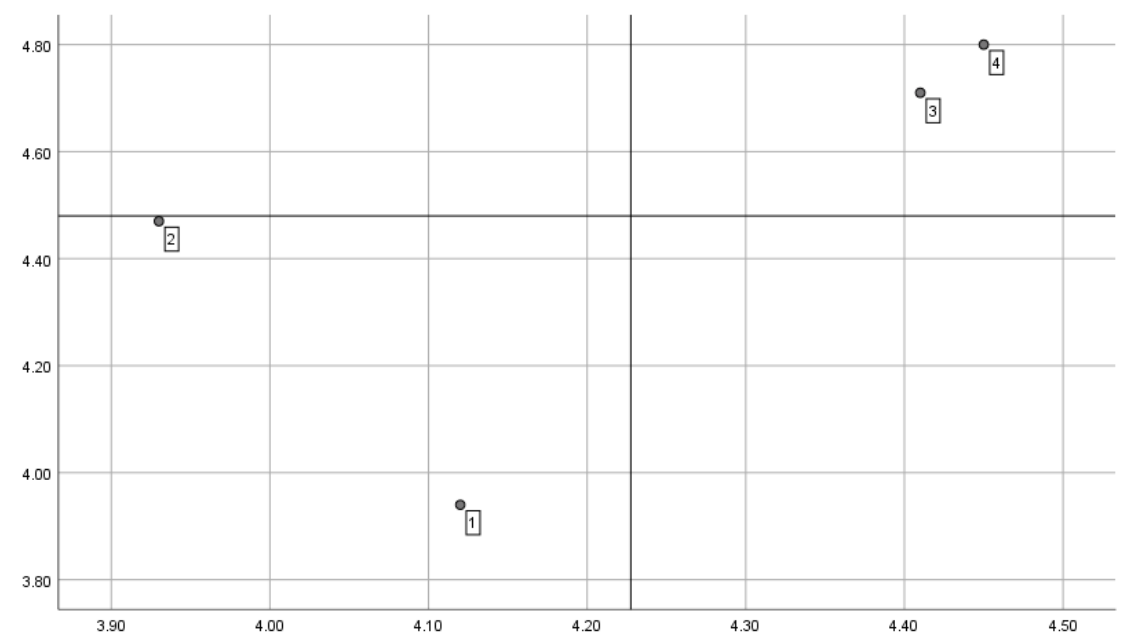

Hope

Figure 2. IPA Matrix

Source : Processed Data, 2021

From Figure 2 of the IPA quadrant, the transformation of social assistance to non-cash are perceived as follows:

(1) The dimensions on time and the right amount are in quadrant III

The transformation of non-cash social assistance in the dimensions of being on time and in the right amount has met the expectations and performance of KPM (beneficiary families) of social assistance

(2) The dimensions are right on target and practically used are in quadrant III

According to the IPA diagram in quadrant III is a dimension that needs to be maintained. The transformation of the distribution of non-cash social assistance in the dimensions of being right on target and practically used has met the expectations and performance of the social assistance KPM.

\section{T test}

This test is used to determine whether the independent variable (X), namely the combo card facility, has a significant effect on the dependent variable $(\mathrm{Y})$, namely saving in the bank.

Table 2. T Test Results

\begin{tabular}{|c|c|c|c|c|c|c|}
\hline \multicolumn{7}{|c|}{ Coefficients $^{\mathrm{a}}$} \\
\hline \multirow[b]{2}{*}{ Model } & & \multicolumn{2}{|c|}{$\begin{array}{l}\text { Unstandardized } \\
\text { Coefficients }\end{array}$} & $\begin{array}{l}\text { Standardized } \\
\text { Coefficients }\end{array}$ & \multirow[b]{2}{*}{$\mathrm{t}$} & \multirow[b]{2}{*}{ Sig. } \\
\hline & & $\mathrm{B}$ & Std. Error & Beta & & \\
\hline \multirow[t]{2}{*}{1} & (Constant) & 3.194 & .514 & & 6.218 & .000 \\
\hline & Fasilities & .592 & .055 & .736 & 10.762 & .000 \\
\hline
\end{tabular}

a. Dependent Variable: Interest in Saving 
Table 2 shows that the $t$ value is 10.762 where the $t$ statistic is greater than the $t$ table, which is 1.98447 and the Sig is 0.000 which is less than 0.005 . Statistically it can be stated that $H_{0}$ is rejected. Thus, the combo card positively affects KPM's interest in saving at the bank.

\section{Financial Inclusion Index}

In 2020 The number of LKD in Tegal City has exceeded the number of conventional branch offices and ATMs, while the data on the number of clever agents and bank branch offices and ATMs are as follows:

Table 3. Number of non-cash service channels

\begin{tabular}{cccc}
\hline Month & LKD & Bank Office & ATM \\
\hline an & 503 & 45 & 82 \\
Feb & 518 & 45 & 82 \\
Mar & 534 & 45 & 82 \\
Apr & 539 & 45 & 82 \\
May & 541 & 45 & 82 \\
Jun & 560 & 45 & 82 \\
Jul & 521 & 45 & 82 \\
Aug & 412 & 45 & 82 \\
Sep & 302 & 45 & 82 \\
Oct & 405 & 45 & 87 \\
Nov & 400 & 43 & 89 \\
Des & 402 & 43 & 89 \\
\hline
\end{tabular}

Contribution of digital financial services agency (LKD)

The contribution of digital financial services agency (LKD) is calculated by number of digital financial services agency (LKD) compared to the total number of channels serving banking services, the calculation is as follows:

Contribution of bank offices

$$
\text { Percentage }=\frac{402}{534} \times 100 \%=75,20 \%
$$

The percentage of bank offices is calculated by comparing the number of bank offices with the number of channels serving banking services, the calculation is as follows:

\section{Contribution of ATM}

$$
\text { Percentage }=\frac{43}{534} \times 100 \%=8,05 \%
$$

ATM contribution is calculated by comparing the number of ATMs with the total number of channels serving banking services. The calculation is as follows:

$$
\text { Percentage }=\frac{89}{534} \times 100 \%=16,67 \%
$$

From the above calculations, it shows that the Smart Practice Agent (LKD) contributes $75.20 \%$ to banking financial services in the City of Tegal. Thus, LKD received very good criteria for financial inclusion in Tegal City from the dimension of the availability of banking services.

\section{Post-Cash Social Assistance Recipient KPM Welfare}

The hypothesis test formula is as follows:

$$
\chi^{2}=\frac{(|A-D|-1)^{2}}{(A+D)}
$$


A: The number of cases observed in cell $A$

$D$ : the number of cases observed in D cells

The following are the results of the analysis based on the welfare classification by BKKBN on the basic fulfillment of non-cash social assistance beneficiary families.

(1) Fulfillment of basic needs

Table 4. Changes in Respondents Basic Need Fulfillment Items Before \& After Receiving Social Assistance

\begin{tabular}{lcc}
\hline & \multicolumn{2}{c}{ After } \\
\cline { 2 - 3 } Before & Not Enough & Enough \\
\hline Not Enough & 8 & 77 \\
Enough & 0 & 15 \\
\hline
\end{tabular}

Based on the table above, of the $100 \mathrm{KPM}$ respondents for social assistance, there are 23 with basic need fulfillment status that has not changed before and after KPM receives social assistance. The KPMs consists of 8 respondents in an insufficient condition and 15 respondents in a sufficient condition. While the rest had a positive impact so that they were able to meet their basic needs, namely as many as $77 \mathrm{KPMs}$

Table 5. Mc Nemar Test Results of Basic Need Fulfillment Items

Test Statistics ${ }^{\mathrm{a}}$

Before and After

\begin{tabular}{lc}
\hline $\mathrm{N}$ & 100 \\
Chi-Square $^{\mathrm{b}}$ & 75.013 \\
Asymp. Sig. & .000 \\
\hline
\end{tabular}

a. McNemar Test

b. Continuity Corrected

From the output of the table statistical data above, it is obtained that the $X$ statistic is 75.013 greater than the $\mathrm{X} 2$ table with degrees of freedom $=1$ at the level $\mathrm{a}=0.05$, namely 3.841 and the Asymp value. Sig of 0,000 is less than 0.025 , so statistically it can be stated that $H_{0}$ is rejected. Thus there is a change in the classification of KPM welfare level based on the fulfillment of basic needs after the distribution of non-cash social assistance.

(2) Fulfillment of the psychological needs of the family

In the case of family psychological, the researcher uses the question aspect of the fulfillment of health services for family members who receive social assistance benefits with the following data.

Table 6. Changes in Respondents Psychological Needs Items Before \& After Receiving Social Assistance

\begin{tabular}{lcc}
\hline & \multicolumn{2}{c}{ After } \\
\cline { 2 - 3 } Before & Not Served & Served \\
\hline Not Served & 27 & 59 \\
Served & 1 & 13 \\
\hline
\end{tabular}

Table 6 shows that the number of respondents who experienced a positive impact was 59 and the remaining 40 respondents did not experience any changes because before receiving social assistance they had access to health services. However, there is 1 respondent who did not get access to health services after receiving social assistance. 
Table 7. Mc Test Results. Nemar. Psychological Needs Items

\begin{tabular}{cc}
\hline $\mathrm{N}$ & 100 \\
Chi-Square $^{\mathrm{b}}$ & 54.150 \\
Asymp. Sig. & .000 \\
\hline
\end{tabular}

a. McNemar Test

b. Continuity Corrected

Table 7 shows that the Chi-Square ${ }^{\mathrm{b}}$ is 54.150 which is greater than the $\mathrm{X} 2$ table with degree of freedom $=1$ at the level $a=0.05$, namely 3.841 and the Asymp value. Sig of 0,000 is less than 0.025 , so statistically it can be stated that $\mathrm{H}_{0}$ is rejected. Thus there is a change in the classification of KPM welfare level based on meeting the psychological needs of the family (psychological needs) after the distribution of non-cash social assistance.

(3) Fulfilling the needs of family development

In terms of development needs, the researcher uses an educational aspect in the form of questions about meeting the needs of school children's equipment with the following data.

Table 8. Changes in Respondents Family Development Needs Items Before \& After Receiving Social

\begin{tabular}{lcc} 
& \multicolumn{2}{c}{ Assistance } \\
\cline { 2 - 3 } Before & Unfulfilled & Fulfilled \\
\hline Unfulfilled & 1 & 65 \\
Fulfilled & 0 & 34 \\
\hline
\end{tabular}

Based on table 8 the number of respondents who experienced a positive impact was 65 and the remaining 35 respondents did not experience changes after receiving social assistance.

Table 9. Mc Test Results. Nemar of Family Development Needs Items

\begin{tabular}{lc}
\multicolumn{2}{c}{ Test Statistics $^{\mathrm{a}}$} \\
\hline $\mathrm{N}$ & 100 \\
Chi-Square $^{\mathrm{b}}$ & 63.015 \\
Asymp. Sig. & .000 \\
\hline
\end{tabular}

a. McNemar Test

b. Continuity Corrected

From table 9, it is found that the Chi-Square ${ }^{b}$ number is 63.015 which is greater than the $X 2$ table with degrees of freedom $=1$ at the level $a=0.05$, namely 3.841 and the Asymp value. Sig of 0,000 is less than 0.025 , so statistically it can be stated that $H_{0}$ is rejected. Thus there is a change in the classification of KPM welfare level based on meeting the needs of family development after the distribution of non-cash social assistance.

(4) Fulfilling the needs of family self-actuality in society (self esteem)

In terms of the need for self-actualization of KPM in the community, researchers use the aspect of participation in religious studies in the KPM environment with the following data.

Table 10. Changes in Respondents' Self-actualization of the family in the community before \& after Receiving Social Assistance

\begin{tabular}{lc|c}
\hline & \multicolumn{2}{c}{ After } \\
\cline { 2 - 3 } Before & Not Active & Active \\
\hline Not Active & 14 & 58 \\
Active & 1 & 27 \\
\hline
\end{tabular}


Based on table 10 number of respondents who experienced a positive impact was 58 and the remaining 41 respondents did not experience changes before and after receiving social assistance while 1 respondent experienced a negative impact.

Table 11 Mc Nemar Test Results of Self-actualization of the family in the community

Test Statistics ${ }^{a}$

\begin{tabular}{lr}
\multicolumn{2}{c}{ Before and After } \\
\hline $\mathrm{N}$ & 100 \\
Chi-Square $^{\mathrm{b}}$ & 53.153 \\
Asymp. Sig. $^{2}$ & .000 \\
\hline
\end{tabular}

a. McNemar Test

b. Continuity Corrected

From table 11, it is found that the Chi-Square ${ }^{\mathrm{b}}$ value is 53.153 which is greater than the $\mathrm{X} 2$ table with degrees of freedom $=1$ at the level $a=0.05$, namely 3.841 and the Asymp value. Sig of 0,000 is less than 0.025 , so statistically it can be stated that $\mathrm{H}_{0}$ is rejected. Thus there is a change in the classification of KPM welfare level based on the fulfillment of KPM's self-actuality needs after the distribution of non-cash social assistance.

Table 12. The summary of the hypothesis testing of KPM welfare indicators according to the BKKBN

\begin{tabular}{lcc}
\hline Welfare indicators & Ho & Ha \\
\hline basic family needs (basic needs), & $\begin{array}{c}\text { rejected } \\
\text { accepted }\end{array}$ & $\begin{array}{c}\text { rejected } \\
\text { accepted }\end{array}$ \\
$\begin{array}{l}\text { psychological needs of the family (psychological } \\
\text { rejected } \\
\text { needs), }\end{array}$ & $\begin{array}{c}\text { accejected } \\
\text { accepted }\end{array}$ \\
family development needs (development & rejected & rejected \\
needs), & accepted & accepted \\
self-actuality of the family in society (self & rejected & rejected \\
esteem) & accepted & accepted \\
\hline
\end{tabular}

Based on the data at Table 12, it can be concluded that the KPM has experienced changes in welfare after receiving non-cash social assistance.

The objective of the non-cash food assistance program (BPNT) is to increase the accuracy of target groups, provide a more balanced nutrition, more choice and control over the poor, encourage people's retail business, provide access to financial services for the poor and streamline the budget. In the long term, the distribution of non-cash food aid is expected to have an impact on improving the welfare and economic capacity of the beneficiaries. This is in line with what Henri Fayol (1949) stated in Kettner (2002), management activity consists of five components: planning, organizing, command, coordination, and control.

In its own implementation, it has something new, namely by paying attention to quantity and quality, including by forming a Food Social Assistance Coordination Team, which is a team formed in stages at the central, provincial and district / city levels to the sub-district level to create harmonization and synergy in the implementation of BPNT and accountability so that they can achieve effective results. In addition, in the form of a control team in the distribution of non-cash social assistance (BPNT) in accordance with Perpres No.63 of 2017, this team is chaired by the Coordinating Minister for Human Development and Culture (PMK), the deputy chairman is the Minister for National Development Planning (BPN). / head of the National Development Planning Agency and the secretariat is the Executive Secretariat of the National Team for the Acceleration of Poverty Reduction (TNP2K), with members of the Ministers and Heads of related institutions including presidential staff, the Governor of Bank Indonesia and the Chairman of the Board of Commissioners of the Financial Services Authority (OJK). As well as BPNT Facilitators are officers who accompany the entire process of 
implementing the BPNT program (including: registration, data replacement, contact information and complaints personnel) consisting of Regency / City Social Welfare Coordinators (TKS), Regency / City Family Hope Program Coordinator (PKH), Sub-district Social Welfare Staff (TKSK), PKH Facilitators and PKH Assistants for difficult areas. This is in line with what Weinbach (1994) stated in Kettner (2002), which states that management can answer as a specific function performed by people in a work environment that can increase productivity and the source of organizational goals.

Currently, the implementation of the program has 6 basic points, which are right on target, right in quantity, time, quality, right in quantity and in an orderly administration. Where the implementation has a plan, as stated by Montana and Charnov (1993), it describes three levels of planning: strategic planning, long-term planning, and operational planning.

\section{CONCLUSIONS}

Based on the analysis and discussion this study finds that there is no gap between KPM's Acceptance and Perception of the transformation of the distribution of social assistance to non-cash, so that KPM supports and accepts the transformation of social assistance. The result shows that the combo card affects KPM's interest in saving at the bank or there is the potential for saving beneficiary families (KPM) with the presence of non-cash social assistance. Furthermore the Agen laku Pandai (LKD) contributes $75.20 \%$ to banking financial services in Tegal City. Therefore, LKD received very good criteria for financial inclusion in Tegal City from the dimension of the availability of banking services. From the 4 welfare indicator classifications, it is found that the KPM has experienced changes in welfare after receiving non-cash social assistance.

Non-Cash Social Assistance in Tegal City is entirely acceptable but there are obstacles in its withdrawal operations, namely the practical element still needs improvement. So that the Social Service as the related Office and KPM assistant needs to socialize to KPM so that non-cash withdrawals can be better understood and the level of acceptance of non-cash social assistance can be better. The transformation of non-cash social assistance affects KPM's interest in using the combo card facility for savings. Like KPMs who are interested in saving with a low-cost combo card facility, banks are expected to be able to expand these facilities to the public at large, so that the public's interest in saving at large can increase. The transformation of non-cash social assistance has contributed positively to financial inclusion in the City of Tegal, so that it can be applied to various distributions of funds from the government to the community in non-cash form. Non-cash social assistance in Tegal City has succeeded in improving the welfare of KPM, in the future the government should be able to map KPM that is prosperous and capable of being independent so that the distribution of social assistance can be contributed to other KPM and can be evenly distributed to the poor in Tegal City.

\section{REFERENCES}

Bank Indonesia, (2014). Booklet Keuangan Inklusif. Jakarta: Bank Indonesia.

Bank Indonesia, (2018). Kajian Stabilitas Keuangan No. 30. Jakarta : Bank Indonesia.

Badan Pusat Statistik Kota Tegal, 2020. Data dan Informasi Kemiskinan Kota Tegal Tahun 2010-2019. Tegal : Badan Pusat Statistik.

Demirguc-Kunt, A., Beck T and Peria MM. (2007). Reaching out: Access to and use of banking services across countries. Journal of Financial Economics 85: 234-266.

Dewan Nasional Keuangan Inklusif - DNKI (2017). Laporan Tahunan Keuangan Inklusif 2017. Jakarta: DNKI

Dixit, R., and Ghosh, M. (2013). Financial Inclution for Inclusive Growth of India a Study of Indian State. International Journal of Business Management \& Research, 3arief_f (1), 147-156.

Fred, W. (1999). Economic Psychology Between Psychology and Economics: An Introdustion. Journal Of International Association of Applied Psychology. 48, 263-272, accessed from https://doi.org L10.1111/i. 14640597.1999.t b00001.x

Habibullah, (2019). Inklusi Keuangan dan Penurunan Kemiskinan: Studi Penyaluran bantuan Sosial Non Tunai. Sosio Informa Vol.5,No.01. 
Hannig, A. and Jansen, S. (2010). Financial Inclusion and Financial Stability: Current Policy issues (Asian Development Bank Institute Working Paper). https://www.adb.org/sites/default/files/publication/156114/adbi-wp259.pdf, accessed 15 July 2020

Kementrian Koordinator Bidang PMK Republik Indonesia, (2017). Pedoman Umum Bantuan Pangan Nontunai. Jakarta: TNP2K.

Kementrian Sosial R.I (2016). Pedoman Pelaksanaan Program Keluarga Harapan. Jakarta: Dit.Jamsos.

Kuncoro, Murdrajat. (2006). Ekonomi Pembangunan, Jakarta: Salemba Empat.

Muhtar, Noviana I., (2016). Potensi Modal Sosial Pada kelompok Usaha Bersama Program Penanggulangan kemiskinan. Sosio Informa 2(2): 155-165

Otoritas Jasa Keuangan (OJK). Strategi Nasional Literasi Keuangan Indonesia. Jakarta : OJK

Otoritas Jasa Keuangan (OJK). Survey Nasional Literasi Keuangan Indonesia 2019. Jakarta: OJK

Rachman B,Agustian A and Wahyudi. (2018). Efektivitas Dan Perspektif Pelaksanaan Program Beras Sejahtera (Rastra) dan Bantuan Pangan Non-Tunai (BPNT). Jurnal Analisis Kebijkan Pertanian 16 (1), 1-18

Republik Indonesia, (2016). Peraturan Presiden Nomor 82 tahun 2016 tentang Strategi Nasional Keuangan Inklusif. Jakarta: Setkab

Republik Indonesia, (2017). Peraturan Presiden Nomor 63 Tahun 2017 tentang Penyaluran Bantuan Sosial Secara Non Tunai. Jakarta: Setkab

Risnandar, W.B. Aditya (2018). Implementasi Program Bantuan Sosial Non Tunai di Indonesia. Jurnal Penelitian dan Pengembangan kesejahteraan Sosial, 7 (3): 146-161

Samputra P. L., Ramadhani, A.W. (2019), Efektifitas Bantuan Sosial Dalam penanggulangan kemiskinan di Tengah Perlambatan Ekonomi Indonesia Dengan pendekatan Non-Parametrik. Jurnal Perspektif Ekonomi Darussalam. 5(1): 10-34 DOI: https://doi.org/10.24815/jped.v5i1.14227

Sanjaya, I.M.,Nursechafia (2016) Financial Inclusion and Inclusive Growth: Across-Provinve Analysis. Bulletin of Monetary Economics And Banking 18 (3): 281-306. https://doi.org/10.21098/bemp.v18i3.551

Sarma, M. (2012). Index of Financial Inclution A Measure of financial sector inclusiveness. Berlin Working papers on Money, finance, Trade and development No.07 https://finance-andtrade.htw.berlin.de/fileadmin/HTW/Forschung/Money_Finance_Trade_Development/workin g_paper_series/wp_07_2012_Sarma_Index-of-Financial-Inclusion.pdf accessed 15 July 2020 